\title{
ELECTRONIC NOSE (E-NOSE) DESIGN FOR ARDUINO NANO-BASED HALAL HARAM IDENTIFICATION
}

\author{
Muaamar Khadafi, Rachmad Almi Putra* \\ Department of Physics, Samudra University \\ Jl. Meurandeh Langsa Aceh 24416, Indonesia
}

Received: $3^{\text {rd }}$ March 2020; Revised: $3^{\text {rd }}$ July 2020; Accepted: $17^{\text {th }}$ September 2020

\begin{abstract}
It has been successfully designed an Electronic Nose (e-Nose) instrumentation system consisting of 6 MQ gas sensors, namely, MQ2, MQ4, MQ5, MQ7, MQ9, MQ135. The E-nose system is used to identify halal-haram food. This E-Nose system uses an Arduino Nano microcontroller. The Graphic User Interface (GUI) system is built with Visual Studio 2008. Then, the data responses will be evaluated by using 2 patterns recognition methods called Principle Component Analysis (PCA). The classification results can be explained by the value of the score plot on the PCA of the data. PC1 accounts for $19 \%$ of the variance, and PC2 accounts for 5\% of the variance, data obtained is stored and displayed on personal computers in Excel format. Each sample was tested for up to ten repetitions. The data obtained from the six sensors in the e-nose was processed using Minitab 18 and it was necessary to obtain classification data on lard, pig oil, and sample B, which were fried crackers using pork oil.
\end{abstract}

Keywords: Halal; Haram; E-Nose; Arduino; Nano

\section{Introduction}

Indonesia is a country with a majority Muslim population, indeed halal and haram food is the main factor that is a concern in the circulation of food products. Despite haram, food products are still circulating widely in Indonesia. ${ }^{1}$ Haram food in my paper is food containing pork, even though it is fat, meat, and the other foods containing pork. The method often used to identify pork fatty acid is to use the HPLC (High-Performance Liquid Chromatography) instrument method, FT-IR (Infra-Red Fourier Transform Spectrophotometer), dan GCMS (Gas Chromatography-Mass Spectrophotometry). ${ }^{2,3}$

This method requires a large cost and it is not easy that makes it difficult for the analysis process. Therefore, another method is needed to classify foods containing pork through scents become an electrical signal (analog), which is converted into a digital signal so that it can be measured which can classify a food containing lard.

\footnotetext{
*Corresponding author.

E-Mail: rachmad.almi@unsam.ac.id
}

In the last few years, the technology Electronic Nose (E-Nose) has become special attention for researchers in identifying food products such as meat because it is rapid, simple, low cost and the system can be varied. E-Nose is one of the electronic instruments that can function to imitate the working concept of the human nose as a detector and analyze the scents. ${ }^{4,9}$ Electronic Nose abbreviated as E-Nose is an artificial olfaction system used to analyze the smell of simple compounds and complex compounds. E-Nose can be applied in various fields, such as food, beverage, chemical, defense, health, etc. In the food industry, e-nose can be used for scents identification which is useful in monitoring the production process. ${ }^{5,9}$

Previous research conducted by ${ }^{5}$ was designed to build an e-nose using 4 TGS sensors that function to detect breast cancer. Further research was conducted by ${ }^{6}$ regarding the detection of beef using E-Nosebased Bidirectional Associative Memory (BAM). The research use 5 sensor types of TGS, which are TGS 2610, TGS 2602, TGS 
2620, TGS 2611, and TGS 2600. Then a study was conducted on the characteristics of gas sensors to determine the freshness of tuna fish using the MQ type sensor, MQ-135, MQ3 , and MQ-4. ${ }^{7}$

In this research, an electronic nose will be built using 6 Arduinonano-based MQ sensors with a responsive level to different volatile gases capable of changing signals (scents) that are converted in the form of analog signals. This research purpose to produce a model of the electronic nose system (e-nose) that can be applied in testing food for halal and haram food. The e-nose system displays the measurement results in the form of a data logger system on a personal computer (PC) which is the next process to reach a conclusion about the fat content of lard in food.

\section{Methods}

\section{Design of system}

The Electronic Nose (e-nose) hardware consists of, sensor circuits, LCD circuits, fans, and heaters, the power supply $12 \mathrm{~V} \mathrm{DC}$ used in this research. The design of the system form is presented in the following figure 1

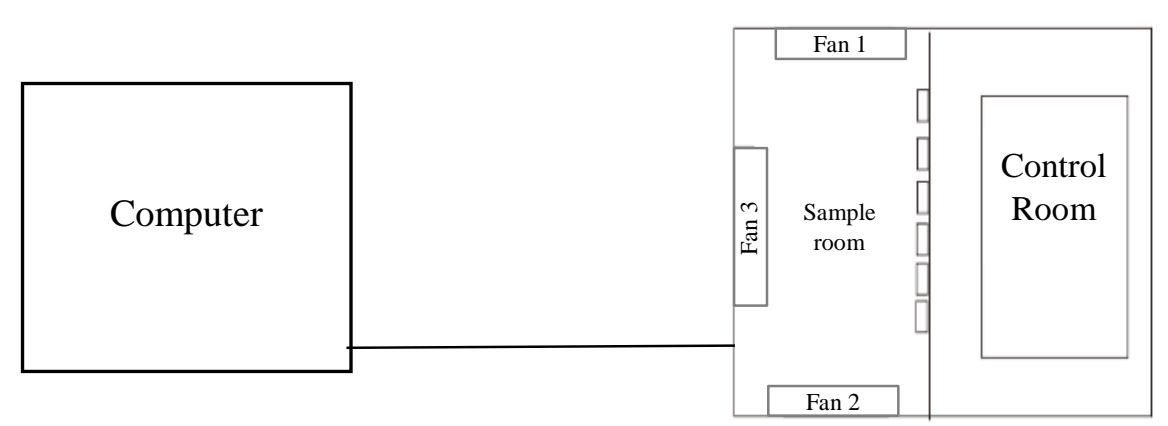

Figure 1. Hardware Design

From figure 1. The hardware design of the e-nose consists of two main spaces, that is a control room that contains components of the device such as a microcontroller, power supply, and a collection of connecting cables. The sample room consists of three fans and one heater with $6 \mathrm{MQ}$ gas sensors.

\section{Design of Software}

To enable e-nose hardware, a controller is needed in the form of software. In this research, the software was built using Arduino IDE and Visual Studio 2008. That Arduino IDE functions to control and run enose hardware and Visual studio 2008 as Data Logger System E-Nose.

\section{Testing Procedure}

\section{Collection of data e-nose}

The E-Nose has two conditions, that is sensing and flushing. Sensing is also known as the odor on, which is a condition in which air has flowed into the sample room so that the scents of the sample can be detected by the sensor and provides analog signals recorded using a data logger. Furthermore, flushing or odor off ${ }^{5}$ when the air odor off is poured out of the e-nose so that the scents are not captured again by the sensor. ${ }^{6,7}$

\section{Processing data}

The sample used was lard and pig oil and crackers fried in pork oil, which was heated at $40^{\circ} \mathrm{C}$ in the chamber which was then sniffed by the MQ Sensor Array.

Processing data was used Principal Component Analysis (PCA). The function of PCA serves to group samples in one group for one testing. So from this testing, we can see a collection of data derived from lard and pork and can be distinguished.

\section{Result and Discussion}

\section{The system testing}

The construction of a microcontrollerbased halal and haram food e-nose detection system has been completed. Tests are carried 
out in stages, that is testing hardware, software.

Based on Figure 2 it can be seen that there has been communication between hardware and software and can run as expected (2a) in Figure $2 b$ shows that the gas sensor is running well

\section{Analysis Results}

The response from the gas sensor in the enose is an analog signal that is captured by air heated from the sample room at $400 \mathrm{C}$ and read as data in the User Interface Graph (GUI) (figure 3).

The data obtained is stored in an excel format. The data is then processed by applying the extraction method of the gradient feature multiplied by the maximum and mean values. The gradient value starts when the sensor starts reading the signal from the sample. Testing for each sample is repeated up to ten times at one-time data collection. And Then, The repetitive sensor response values were processed using gradient feature extraction and then obtained by PCA method using Minitab 18 software. PCA analysis results are presented in PCA score plot (figure 4) for lard, pig oil, and sample B. Sample B is fried crackers using pork oil.

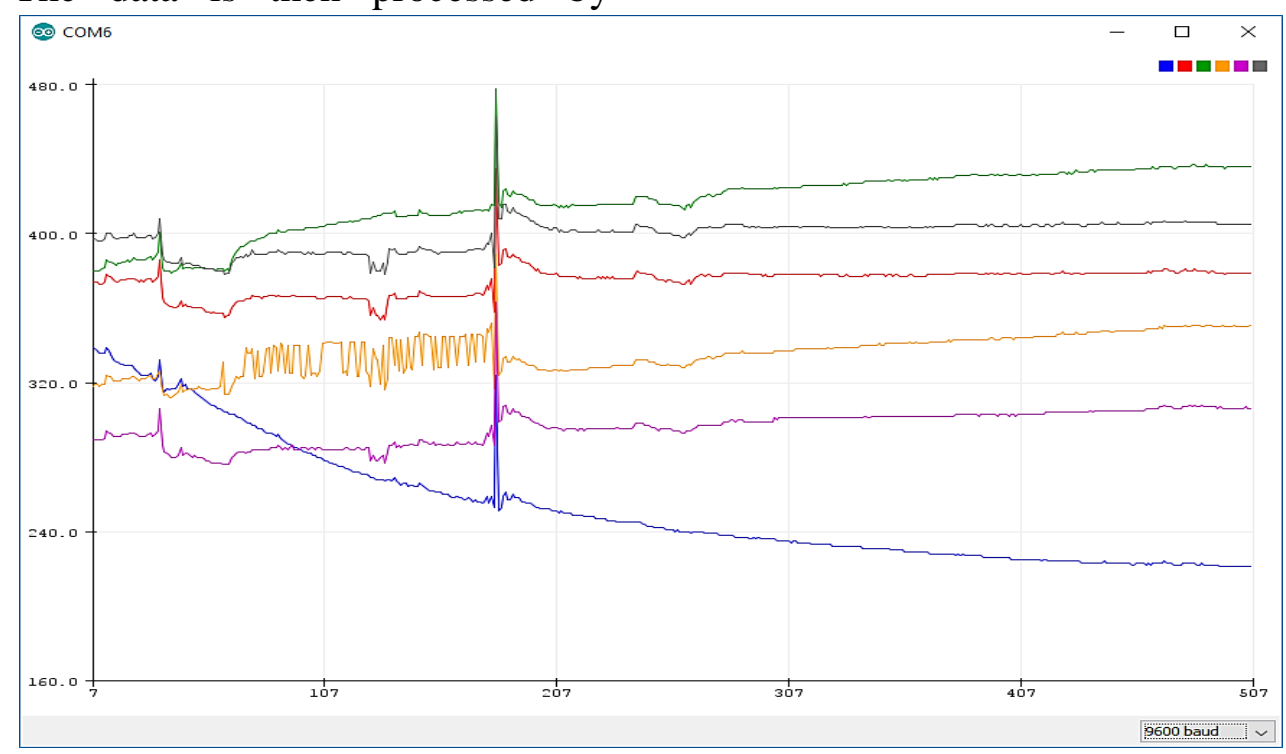

Figure 2. E-Nose Serial Communication with PC Computers

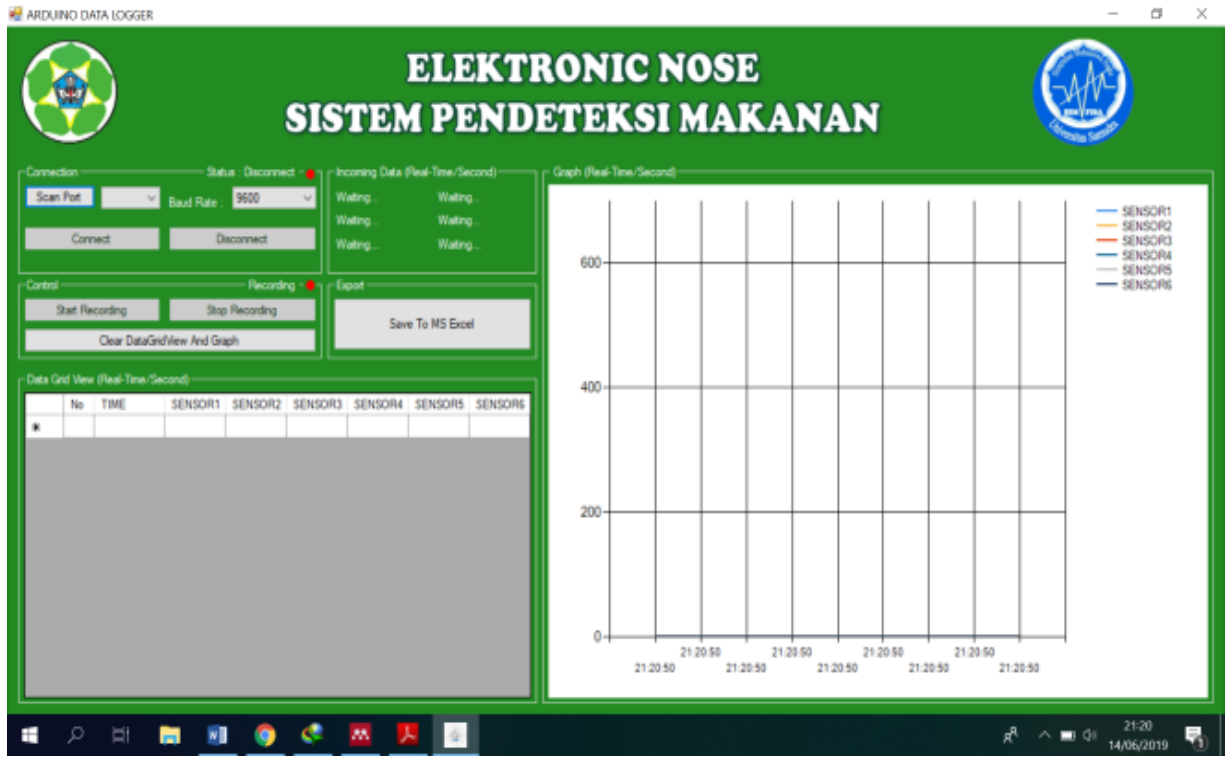

Figure 3. The GUI of E-Nose Food Detection 


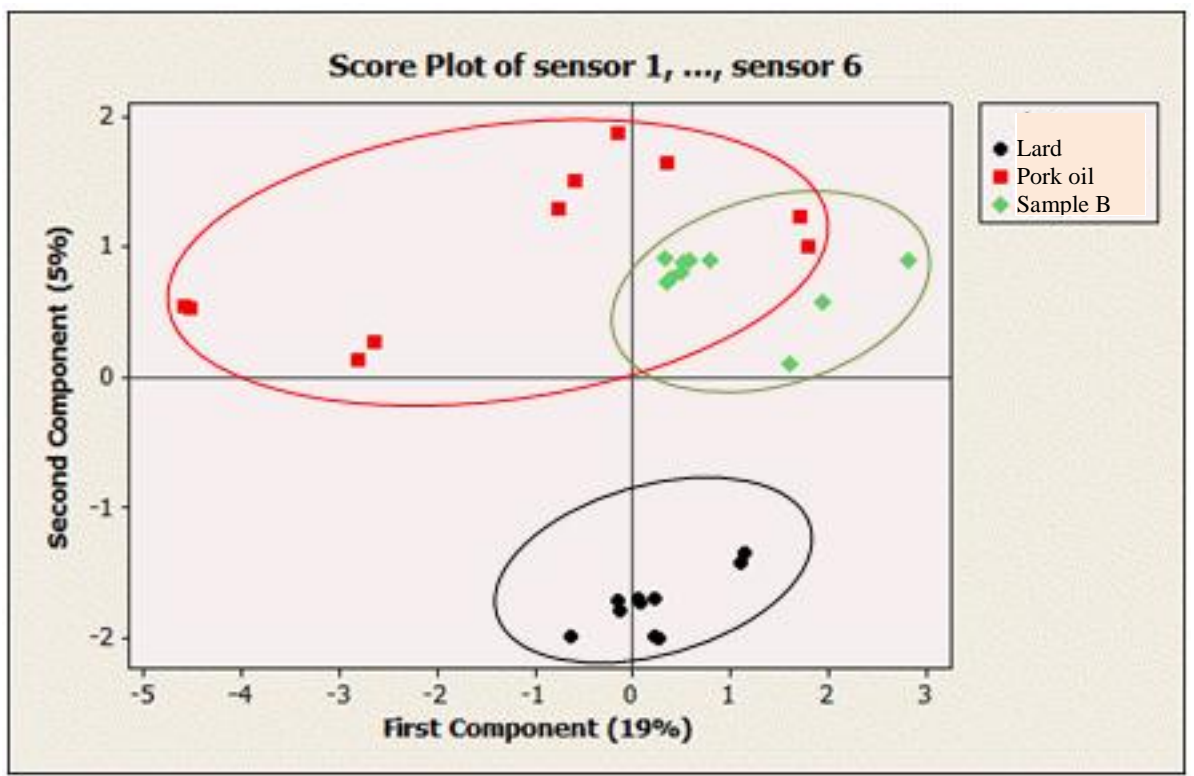

Figure 4. PCA score plot for food samples containing pork oil

The graph presented in Figure 4 can be used to find out groupings and trends. Based on Figure 4, it can be seen that there are two data groupings namely $\mathrm{PC} 1$ and $\mathrm{PC} 2$ with different percentages, PC1 accounts for $19 \%$ of the variance, and PC2 accounts for $5 \%$ of the variance. Then that three groups of data sets appear, namely the lard, pork oil, and sample B. This shows that the nose can be grouped based on the character of the sample

\section{Conclusion}

From the research that has been conducted on the design of the nose electronic system (e-Nose) to identify illegally based nanobased halal foods, it can be concluded that the output value of the six sensors from the enose system designed can identify foods containing lard fat efficiently in distinguishing different types of samples.

\section{Acknowledgments}

The author would like to thank the Ministry of Education and Culture of Higher Education for providing research funding through the creativity program of the 5 funding fields in 2019.

\section{References}

1. B. P. Street. Characterization of Mobile e-
Nose for Halal Detection Device. pp. 0-2.

2. H. Barroroh. Identifikasi Pola Spektra Infra Merah Khas Protein Daging Sapi dan Babi Menggunakan Metode Second Derivative (2D). Universitas Islam Negeri Maulana Malik Ibrahim. 2014.

3. S. Hermanto, A. Muawanah, and R. Harahap. Profil dan Karakteristik Lemak Hewani (Ayam, Sapi dan Babi) Hasil Analisa FTIR dan GCMS. J. Kim. 2008;1(3):102-109

4. R. M. Schnabel et al.. Electronic nose analysis of exhaled breath to diagnose ventilator-associated pneumonia. Respir. Med.. 2015;109(11):1454-1459

5. G. Y. Sari, W. Wildian, and N. Firmawati. Rancang Bangun Sistem Electronic Nose (E-Nose) Untuk Deteksi Sampel Kanker Payudara Berbasis Mikrokontroler Arduino Uno. Jurnal Ilmu Fisika Universitas Andalas. 2018;10(1):1-10

6. E. F. Anggara, T. W. Widodo, and D. Lelono. Deteksi Daging Sapi Menggunakan Electronic Nose Berbasis Bidirectional Associative Memory, IJEIS (Indonesian J. Electron. Instrum. Syst.. 2017;7(2):209

7. Adam. Seminar Nasional Industri dan Teknologi (SNIT). Politeknik Negeri Bengkalis. 2018:247-258,

8. C. A. Lintang, T. W. Widodo, and D. Lelono. Rancang Bangun Electronic Nose 
untuk Mendeteksi Tingkat Kebusukan Ikan Air Tawar. IJEIS (Indonesian J. Electron. Instrum. Systems. 2017;6(2):129-140

9. Tazi, I. et al., Design and testing of electronic nose for determining the pattern of bad breath classification in patients with diabetes mellitus and pulmonary tuberculosis (TBC) AIP Conference Proceeding; 2021. p. 050004 